\title{
The English Sweating Sickness: Out of Sight, Out of Mind?
}

\author{
Paul Heyman ${ }^{1}$, Christel Cochez ${ }^{2}$, Mirsada Hukić ${ }^{3}$
}

${ }^{1}$ Research Laboratory for Vector-Borne Diseases, Queen Astrid Military Hospital, Brussels, Belgium, ${ }^{2}$ Veterinary Unit Queen Astrid Military Hospital, Brussels, Belgium, ${ }^{3}$ Department of Medical Science, Academy of Sciences and Arts of Bosnia and Herzegovina, Sarajevo, Bosnia and Herzegovina

Correspondence: paulheyman@telenet.be Tel.: + 32496843340

Received: 8 May 2017

Accepted: 5 April 2018

Key words: English sweating sickness - Sudor anglicus - Hantavirus - Picardy sweat Hantavirus cardiopulmonary syndrome.
In this paper we aim to add additional knowledge regarding the occurrence, origin and epidemiological features of the English sweating sickness. The English sweating sickness raged in five devastating epidemics with mortality rates between 30 and 50\% between 1485 and 1551 throughout England, and on one occasion also affected mainland Europe, in 1529. The Picardy sweat, generally considered as the English sweating sickness' lesser deadly successor, flared up in France in 1718 and caused 196 localized outbreaks with varying severity all over France and neighboring countries up to 1861. The English sweating sickness has been the subject of numerous attempts to define its origin, but so far all efforts have failed due to lack of material, DNA or RNA, that - using modern techniques and knowledge - could shed light on its cause. Although the time frame in which the English sweating sickness occurred and the geographical spread of the outbreaks is generally known, we will demonstrate here that there was more to it than meets the eye. We found reports of cases of sweating sickness in years before, after and between the 1485, 1508, 1517, 1529 and 1551 epidemics, as well as reports of sweating sickness in Italy and Spain. Conclusion. In spite of the fact that the English sweating sickness apparently has not caused casualties for a more than a century now, we suggest that -given the right circumstances- the possibility of re-emergence might still exist. The fact that up until today we have no indication concerning the causal pathogen of the English sweating sickness is certainly not re-assuring.

\section{Introduction}

The English sweating sickness (hereinafter referred to as ESS) struck, according to general belief, for the first time at the very beginning of the reign of Henry VII, in August 1485 , and re-emerged in 1507, 1517, 1528 and 1551 . Webster however mentioned that -according to Erasmus- the ESS first appeared in 1483 and re-emerged in 1485 (1), while, an account in the York Civic Records mentioned a pestilence in the area $(\mathrm{N}-\mathrm{E}$ England) in June 1485, that bore a great re- semblance to the sweating sickness. This was three months before the Battle of Bosworth Field that brought an end to the War of the Roses and the reign of Richard III (2). The irregular intervals between the five epidemics $(22,10,11$ and 23 years respectively) suggest an endogenous, ecological or meteorological trigger.

The fact that the onset of the disease was quick, deadly and without warning invariably caused panic in the affected population. Holinshed wrote: "so sharp and deadly that 
the lyke was never hearde of to any manne's remembrance before that tyme" (3). The ESS was new and unknown, struck without warning, killed often hundreds per week and disappeared apparently for no reason after one or two months. These short episodes did not however cause a general population decline, as did the plague in the $14^{\text {th }}$ century (4). The first symptoms were chills and tremors, quickly followed by high fever and great weakness. The body was covered with perspiration but a rash was rarely reported. The course of the disease was exceptionally violent and sometimes fatal within hours. The mortality rate was highly variable, but probably between 30 and $50 \%$. In comparison, the overall mortality from the 1346-1353 plague epidemic was estimated at $30 \%$ to $60 \%(5,6)$. Zinsser cites ESS mortality as high as 80 to $90 \%$ (7), but Creighton reports a mortality of $5 \%$ (8). The ESS thus emerged around 1480, caused five major epidemics [1485, 1507, 1517, 1528, 1551], and then apparently disappeared, until a more benign variant -the Picardy Sweat- emerged in France more than 150 years later (9).

In the $14^{\text {th }}$ century, the Black Death (Yersinia pestis) caused the worst natural disaster that mankind has ever experienced, and considerably reduced the population in both Asia and Europe (10). Both continents recovered slowly and despite the fact that political and religious turmoil hampered progress, the fifteenth and sixteenth centuries produced significant progress in science, medicine and in general in the quality of life. Besides the plague, several other new diseases emerged in this era, e.g. syphilis, the Dancing Mania, influenza and the ESS or Sudor Anglicus. Some were here to stay; others apparently disappeared without a trace (i.e. the Dancing Mania (11) and ESS). Europe however did not have the monopoly on devastating epidemics. A new disease called Huey Cocoliztli, emerged in Mexico for the first time in 1545-1548, and re- emerged in 1576-1578. These two epidemics killed an estimated 5-15 million and 2-2.5 million people, respectively, or up to $80 \%$ of the native population. It was remarkable that the disease affected only the local Aztec populations and left the Spanish invaders untouched, like the ESS that apparently struck the English by preference. Acuna-Soto and co-workers give a summary of symptoms that vaguely resemble those of what we call ESS: "The disease had a very short course, lasting three to five days. It started abruptly with high fever, vertigo, severe headache, insatiable thirst, red eyes and weak pulse. Patients became intensely jaundiced, very anxious, demented and restless. They did not tolerate any blanket over their skin...." (12-14). It was also suggested that the Huey Cocoliztli was a viral hemorrhagic fever with a murine vector $(15,16)$.

As the plague, influenza appears to be an ancient disease. The symptoms of human influenza were already described by Hippocrates, roughly 2,400 years ago (17). The virus seems to have caused epidemics throughout human history (18). With the arrival of Christopher Columbus, the virus was introduced to the Americas, and almost the entire indigenous population of the Antilles was killed by an epidemic resembling influenza that broke out there in 1493 (19). The best known and probably the most lethal outbreak was the so-called Spanish flu pandemic (type A influenza, subtype H1N1) which continued through both 1918 and 1919 , with an estimated death toll of 50 to 100 million people worldwide (20).

In this paper we aim to add additional knowledge regarding the occurrence, origin and epidemiological features of the English sweating sickness.

\section{Out of sight, out of mind}

The history of the world is intertwined with that of infectious diseases. The impact, in 
the absence of effective medication, on the population is in some cases devastating, especially when the cause is unknown, and superstition (meteorites, earthquakes, divine punishment, etc. were often implicated) creates confusion and fear. Nevertheless, efforts to explain disease and infection more scientifically have been made throughout history, Hippocrates wrote about the spread of disease by means of air, water and location, and constructed hypotheses on the association between diet, climate and living conditions (21). In contrast to our era, in which we address epidemics with concerted and international action, epidemics (plague, syphilis, smallpox, cholera, yellow fever, typhoid fever, and other infectious diseases) occurred in antiquity and in the pre- $20^{\text {th }}$ century era regularly and were in a sense the norm (22). In most cases there was no effective treatment available. A hallmark of various epidemics was that they were a constantly lurking danger. A few, e.g. ESS, Dancing Mania, and Huey Cocoliztli, emerged, raged for years or even decennia, and apparently disappeared without good reason.

From what we know today about infectious diseases, i.e. they are caused in general by bacteria and viruses, it is probable that a certain infectious disease will not spontaneously disappear unless we eradicate the causal agent, vaccinate or medicate. In other words: very few pathogens vanish without a trace. In 1992, Lederberg and co-workers defined six categories of factors that could explain the emergence or re-emergence of infectious diseases. These factors are: human demographics and behavior; technology and industry; economic development and land use; international travel and commerce; microbial adaptation and change; and the breakdown of public health measures (23).

From what we know about the fifteenth and sixteenth centuries (see also the next chapter), five of the six determining factors played their role, there is only no evidence of microbial adaption. Why then did ESS apparently disappear after 1551? Perhaps the medieval ESS epidemics were the proverbial tip of the iceberg, an accepted characteristic of most zoonotic disease manifestations. The causal agent might still be around, but the triggering factors for emergence of ESS are now no longer present. There is, however, no guarantee that, should Lederberg's six factors apply again, re-emergence is out of the question.

\section{Setting the scene: England during the peak of the English sweating sickness (fifteenth and sixteenth centuries).}

Central to all social change in the fifteenth century was the occupational shift. As a result of the human toll the plague took in England in the $14^{\text {th }}$ century, villein (serf) labour largely disappeared. Landlords increasingly abandoned direct management of their estates in favour of a leasehold system. In many cases they faced growing arrears of rent and found it difficult to maintain their income levels. They solved the labour shortage problem by converting their holdings to sheep pasture but, in order to achieve this, massive land enclosure took place. This meant deforestation on a massive scale and the subsequent important disruption of fauna and flora. This period could also be considered as the golden age for the English labourer, although individual prosperity varied widely. There was a well-developed land market system among peasants, some of whom managed to rise above their neighbours and began to constitute a yeomen class that extended their trade beyond the island, trading with, for instance, France, The Netherlands and Germany, which became important trading partners.

Remarkable and peculiar is that, although the overall living standards improved, sanitary conditions in English medieval cities, 
streets and houses had a very bad name all over Europe. This was mentioned by several contemporary authors. Jortin mentions: "Erasmus, speaking of the sweating sickness, in a letter to Franciscus, Wolsey's physician, ascribes the sweating sickness, partly to the incommodious form and bad exposition of the houses, to the filthiness of the streets, and to the sluttishness within doors. The floors, says he, are commonly of clay, strewed with rushes, under which lies unmolested an ancient collection of beer, grease, fragments, bones, spittle and excrements of dogs and cats, and everything that is nasty..." (24). Ironically, London in fact needed the Great Fire of the 2 nd to $6^{\text {th }}$ September 1666 to more or less clean up the city. Despite their vital importance for trade and commerce, towns remained as a rule small, with London as the exception. From a population of about 60,000 or 70,000 around 1500 , it grew to about 250,000 inhabitants by 1600 , and this exponential growth probably made it a prime target for epidemics.

\section{The identity and origin of the English sweating sickness}

This suggests that a combination of environmental disruption, more intensive interhuman contact through trade and a growing population facilitated the largely unnoticed transmission of the disease in rural areas, up to the point when the pathogen hit the cities and found ample opportunity in the poor sanitary conditions to cause epidemics that caught attention because of their magnitude, and because ESS also affected and even seemed to preferentially target the rich and mighty. It gained a fearsome reputation.

An extensive search for records of ESS cases (more than 800 books, manuscripts, scientific papers, reports, journals and city archives dating from the $16^{\text {th }}$ to $21^{\text {th }}$ centuries from English, French, Dutch, German, Italian and Spanish authors, and Turkish and Russian literature translated into English, French or German ), showed that before, after and between the five major epidemics, sporadic cases occurred in Britain, as well as in mainland Europe. This suggests a source, most likely animal, that was always present, although probably in fluctuating numbers, but only triggering major epidemics when the population peaked.

In a previous publication, we have already described in detail what we assume to have been the most likely candidate for ESS, i.e. a hantavirus, probably now extinct or mutated (9). A candidate also suggested as the cause of the ESS was an ancient variant of anthrax. However, in the fifteenth and sixteenth centuries, Britain was divided in two major agricultural regions. South of the "watershed" line that roughly runs from Liverpool to Grimsby, the main agricultural activity consisted of grain production, while north of the line the production of livestock, mainly sheep but also cattle, prevailed. It was estimated that in the $15^{\text {th }}$ century there were five times more farm animals (cows and sheep) than humans in that northern region. Should anthrax (the cause of "woolworkers disease") have been the cause of ESS, it would appear logical that the North rather than the South would have been affected. In the southern part of Britain a rodent-borne disease, such as a hantavirus disease, was however more likely to occur than in the North because of the specific food available (25). It has been well established that the ESS only struck England and Wales, never Scotland. Despite an intensive search on our side, we were not able to retrieve reports or even short notes on any increased presence of rodents/ticks/lice/mosquitoes in the ESS epidemic years. Animal-to-human transmission or human-to-human transmission was clearly not an option for contemporary scientists. The absence of such reports makes it difficult to find an explanation for the emergence and re-emergence 
of the ESS. On the other hand, we noticed solitary ESS cases in many years in-between the five epidemics, which would suggest the constant- presence of the causal agent and vector, but much less in non-epidemic years. It should also be taken into account that in the $15^{\text {th }}-16^{\text {th }}$ centuries, England (which had a bad reputation for domestic cleanliness all over Europe) that all sorts of animal species could frequent habitations on a regular basis.

It is remarkable that the emergence of ESS coincided with the Ottoman invasion in Eastern Europe. There is however no convincing proof for the often cited suggestion that the sweating sickness originated from the Ottoman attack on Rhodes (1480) and was brought to Western Europe by soldiers returning from that war in 1483 . Also there are no reports of any ESS-like epidemic amongst Ottoman troops at Rhodes or anywhere in Eastern Europe during their conquest (1453-1683). Bordier writes: “....In the south it (the sweating sickness) invaded Württemberg, the Duchy of Baden, the Palatinate, Bavaria, and Vienna, which at that time was being besieged by the Turks. This was its extent and it did not strike the Turks. ..." (26). It thus appears that is was, and often still is, easier to blame "foreigners" without good reason or proof, than to look for the reason closer to home. In the case of the ESS, the "foreigners" were the Ottoman Turks or the "French" mercenaries (in reality many nationalities, i.e. Swiss and Germans, were represented in that group) hired to fight the Battle of Bosworth for Henry VII.

It thus also seems highly unlikely that the ESS was imported from France by Henry's mercenaries (an unsupported assumption by John Caius, written down more than 60 years after the facts) as the ESS was never mentioned in France around 1485. There is also no mention of ESS victims in Henry's army during the landing in Cornwall on the $7^{\text {th }}$ August or during the Battle of Bos- worth (22 ${ }^{\text {nd }}$ August 1485). A few days after the Battle of Bosworth, the ESS broke out in Oxford, a city more than $120 \mathrm{~km}$ away from Henry's allegedly infected army (27). It seems highly unlikely that the disease could have travelled from Henry's army to Oxford in such a short time.

There is, on the other hand, evidence that the ESS raged in York ( $180 \mathrm{~km}$ North of Bosworth) in 1485 (28) and it could be that various local troops that were joining the army of Richard III (Richmond's adversary and then king of England) were infected during their march to the South and transmitted the disease during and after the Battle of Bosworth to the troops of Richmond (later Henry VII). This hypothesis allows two possible carriers for the disease to London: the victorious Richmond army and parts of the defeated army. The disease could thus well have been local rather than foreign. At the same time, this hypothesis would argue for human-to-human transmission. We have already examined the possibility of humanto-human transmission in a previous paper (9) and found that the epidemic progress fitted 16th century travelling times, i.e. travel on foot, with luggage: 15-20 km/day (75-100 $\mathrm{km}$ per week), travel on horseback, no spare horse: 30-40 km (150-200 km per week), travel on horseback, with a spare horse: 40 $60 \mathrm{~km}$ (200-300 km per week). According to von Marval writing about the progress of ESS in Germany in 1529, these travel speeds are in alignment with the epidemic's progress. Although it should be said that the wise traveler would prefer travelling by water (sea or river) as this was much safer, less exhausting and even faster most of the time, when a detour had to be taken. The same author -Southwood, (28) cited Holinshed who mentioned that in 1252 "sweats, agues and other diseases..." prevailed in England (29). Holinshed unfortunately did not specify further.

Dr Dyer's research, based on parish registers, represents a comprehensive analysis 
of the demographic impact of the five outbreaks of the sweating sickness. Contemporary impressions of the strong age, class, and sex characteristics of the victims of the sweating sickness (young, rich males) are modified to give a more dispassionate and informed picture. He also shows how the sweating sickness was predominantly a rural rather than an urban disease, with a limited overall demographic impact, and that there may have been occurrences outside the five "classic" epidemic years (30). The underlying hypothesis is that the causative agent of the sweating sickness was spread by human-to-human contact as well as initially through a zoonotic or an environmental vector. Dyer shows that, when London was affected in the early weeks of July, there was a distinct male preponderance of victims, although the total number of deaths was not strikingly high. This male preponderance was not always paralleled outside the capital.

\section{The bummock of the iceberg}

In zoonotic diseases, the "tip of the iceberg" principle, i.e. the fact that the outbreaks or epidemics we observe in epidemiological surveillance only represent the obvious part of the total outbreak, is well known. The "bummock of the iceberg" is that almost invisible part that often escapes the attention and reporting because solitary cases occur.

It is widely accepted that ESS indeed caused five important epidemics and had a major impact in the affected regions. In addition, our literature search revealed several other records of ESS victims, often outside the timeframe of the five epidemics (Table 1). The ESS apparently appeared, according to the records, for the first time in 1483 (1) (32) and was last described in Röttingen,

${ }^{1}$ For those of us that are not encountering icebergs on a daily basis: the hummock is the part of an iceberg above water, the bummock is the part under water (31).
Germany as late as $1802(33)$. The time span between the first and last documented appearances thus was a staggering 309 years (1493 to 1802), which indicates that is was not at all a one-day fly. We have found 20 different references so far accounting for one or multiple consecutive years in which the ESS took its toll (Table 1).

All the epidemics affected England, but in 1529 most of Europe suffered heavily from ESS. From England the disease passed on the $24^{\text {th }}$ July to Hamburg, Germany, by ship (34), turned West towards The Netherlands and Flanders, where it caused casualties in September. Given the intensive trade by ship between England and The Netherlands, is remarkable that the ESS apparently arrived overland rather than by sea.

In late September 1529 it reached Denmark and the Scandinavian Peninsula. In Sweden, Magnus Eriksson, the son of King Gustav Vasa succumbed to it $(34,35)$. No precise records could be found regarding the appearance of ESS in Russia (36) (or Muscovy, as the Moscow duchy was called up until 1480). Even Hecker was not sure when he reported: "That the Sweating Sickness likewise penetrated into Lithuania, Poland, and Livonia, if not into a part of Russia, we know only in a general way" (37). Although concise, we also found a reference to the occurrence of the ESS in 1529 in Cremona, Northern Italy $(38,39)$. This was perhaps not all too surprising as in that year most of Europe suffered from the disease.

There are also some rare references to ESS outbreaks in Spain, unfortunately without mention of dates or locations. Von Niemeyer wrote: "Regarding the geographical range of sudor anglicus..... Its home is in France, southwest Germany, and Italy, while in the Netherlands, middle and northern Germany, and latterly in Spain, it has only been met with in occasional epidemics" (40). Heylyn noted that, as also seen in Calais, France in 1517, only the English fell victim to the ESS 
Acta Medica Academica 2018;47:102-116

Table 1. Occurrence of the English Sweating Sickness over time

\begin{tabular}{|c|c|c|c|c|c|c|c|c|c|c|c|c|c|}
\hline & Year & Country & JAN & FEB & MAR & APR & MAY & JUN & JUL & AUG & SEP & OCT & NOV \\
\hline 2 & 1485 & England & - & & & & & & & $\begin{array}{l}\text { Bosworth } \\
{[2]}\end{array}$ & $\begin{array}{l}\text { London } \\
(15000)\end{array}$ & & \\
\hline 3 & 1489 & & \multicolumn{11}{|c|}{ Netherlands, Belgium, continued for 2 yrs [3] } \\
\hline 5 & $\begin{array}{l}1491- \\
1492\end{array}$ & Ireland & \multicolumn{8}{|c|}{ Cork [4], Meath [5] } & & & \\
\hline 6 & 1508 & England & & & & & & & & $\begin{array}{l}\text { London, } \\
\text { Greenwich, } \\
\text { Eltham, } \\
\text { Chester(91) } \\
{[2]}\end{array}$ & & & \\
\hline \multirow{3}{*}{8} & \multirow{3}{*}{1517} & England & & & & & & & & \multicolumn{4}{|c|}{$\begin{array}{l}\text { London(10000), Oxford(400), Cambridge, } \\
\text { Chester [2] }\end{array}$} \\
\hline & & France & & & & & & & & Calais & & & \\
\hline & & Germany & & & & & & & & [6] & & & \\
\hline 9 & 1522 & & & & & & & \multicolumn{2}{|c|}{$\begin{array}{l}\text { Norfolk, England } \\
\text { - [7] }\end{array}$} & & & & \\
\hline 10 & 1526 & Flanders & & & & & & \multicolumn{2}{|c|}{ Ghent (33) [8] } & & & & \\
\hline 11 & 1528 & England & & & & & & \multicolumn{2}{|c|}{$\begin{array}{l}\text { London (2000), } \\
\text { Kent [2] }\end{array}$} & & & & \\
\hline \multirow[b]{3}{*}{12} & \multirow[b]{3}{*}{1529} & France & & & & & & $\begin{array}{l}\text { Aix } \\
(1000) \\
{[11]}\end{array}$ & & & & & \\
\hline & & $\begin{array}{l}\text { Nether- } \\
\text { lands }\end{array}$ & & & & & & & & E-Friesland & $\begin{array}{l}\text { Amster- } \\
\text { dam }\end{array}$ & $\begin{array}{l}\text { 03/10 } \\
\text { Zierikzee }\end{array}$ & \\
\hline & & Germany & & & & & & & $\begin{array}{l}\text { Hamburg } \\
25 / 07 \\
(2000), \\
31 / 07 \\
\text { Lübeck(), } \\
\text { Bremen(), } \\
\text { Verden(), }\end{array}$ & $\begin{array}{l}\text { 14/08 } \\
\text { Mecklen- } \\
\text { burg, 27/08 } \\
\text { Stettin, } \\
\text { Wismar, } \\
\text { Demmin, } \\
\text { rostock, } \\
\text { Stralsund, } \\
\text { Greifswald, } \\
\text { Hanover, } \\
\text { Göttingen, } \\
\text { Brunswick, } \\
\text { Lüneburg, } \\
\text { Waldeck, } \\
\text { Einbeck, } \\
\text { Hadeln, }\end{array}$ & $\begin{array}{l}\text { 01/09 } \\
\text { Danzig, } \\
08 / 09 \\
\text { Königs- } \\
\text { berg, } \\
\text { Westpha- } \\
\text { len, We- } \\
\text { ser valley, } \\
11 / 09 \\
\text { Frankfurt, } \\
13 / 09 \\
\text { Worms, } \\
30 / 09 \\
\text { Marburg, } \\
15 / 09 \\
\text { Julich, } \\
\text { Cologne, } \\
24 / 09 \\
\text { Speyer }\end{array}$ & $\begin{array}{l}06 / 10 \\
\text { Augsburg, } \\
24 / 10 \\
\text { Stras- } \\
\text { bourg, } \\
\text { Freiburg, } \\
\text { Mühl- } \\
\text { hausen, } \\
\text { Gebweiler }\end{array}$ & $\begin{array}{l}\text { Würtenberg, } \\
\text { Baden, } \\
\text { Upper Rhin, } \\
\text { Constance } \\
\text { Lake, }\end{array}$ \\
\hline
\end{tabular}


Continuation of Table 1. Occurrence of the English Sweating Sickness over time

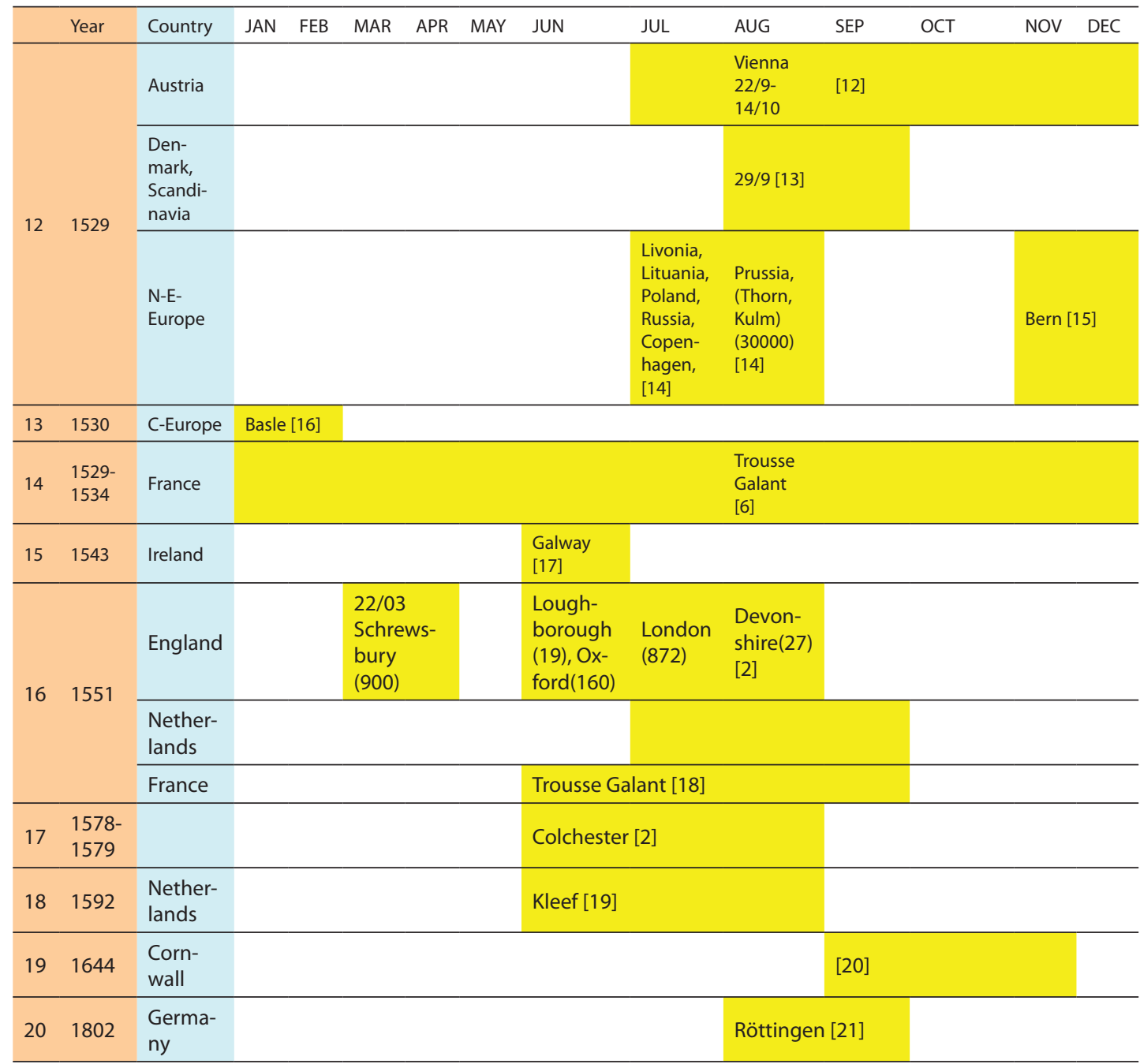

In yellow: month(s) of occurrence of English Sweating Sickness, if reported. Exact dates if reported; ()=The number of reported deaths (probably estimates and, most likely; underestimated numbers), if reported; []= reference.

\section{References to table}

1. Froude JA (1894) Life and Letters of Erasmus. Charles Scribners' sons, New York.

2. Creighton C (1891) The Sweating Sickness, 1485 1551. In: Hist. Epidemics Br. Cambridge University Press, London, pp 237-279

3. De Bruyn H (1870) Histoire deléglise de SainteGudule et du très-Saint sacrement de miracle à Bruxelles. H. Goemaere, Bruxelles

4. Smith C (1815) The Ancient and Present State of the County and City of Cork. John Connor, Cork

5. Shrewsbury JFD (1970) A History of Bubonic Plague in the British Isles. Cambridge University Press, Cambridge, UK
6. Vanden Honert J (1757) Verklaring van de Algemeene Brieven van de Apostelen Jacobus, Petrus, Joannes en Judas. Isaac Tirion en Jacobus Loveringh., Amsterdam

7. Cromwell D (1818) Excursions in the County of Norfolk. Longman, Hurst, Rees, Orme, Brown \& Green, London, UK

8. Anon. (1858) De Navorscher. Ipenbuur\&Van Seldam, Amsterdam

9. Anon. (1863) Dingen die niet Iedereen weet. De Erven F. Bohn., Haarlem

10. Anon. (1934) Bulletijn van den Dienst voor Geschiedkundige en Folklorische Opzoekingen in Brabant .De Brabantsche Folklore. Dienst voor Geschiedkundige en Folklorische Opzoekingen, Brussel 
11. De Noortvelde B (1845) Tableau Fidèle de Troubles et Révolutions. EMM. Hoyois, ImprimeurLibraire, Mons

12. Linzbauer FX (1852) Codex Sanitario-Medicinalis Hungariae. Cazarko Regiar Scientiarum Universitatis, Buda

13. Hecker JFC (1846) The Epidemics of the Middle Ages., 3rd Edition. Trübner\&Co, 60, Paternoster Road, London, London

14. Hecker JFC (1865) Die Grossen Volkskrankheiten der Mittelalters., August Hirsch. Th. Chr. Fr. Enslin, Berlin

15. Guggenbühl JJ (1838) Der Englishe schweiss 1529 in der Schweis. N. Rappler, Lichtensteig

in Spain: "The sweating sickness..., although this should be in an entirely different climate, as in the present instance was the case with the English who were living in Spain ..." (41).

Intriguing reports on the sweating sickness appear in Bryden's "Epidemic Cholera in the Bengal Presidency." (42), Murray's "On the Malwah Sweating Sickness." (43) and Orton's "An Essay on the Epidemic Cholera of India." (44). The ESS is said to have appeared in Malwa (1839) in CentralIndia; Meean Meer (1852), the former Lahore Cantonment during the British period; Peshawar (1855), in North-West Pakistan; and Agra (1859), in the northern state of Uttar Pradesh, India (42). The chances are however that, given the geographical and time discrepancies, these epidemics were of another nature than true ESS, most probably severe or fatal cholera cases.

An intriguing question is why there were such irregular time gaps between outbreaks. The ESS was typically a summer phenomenon, but did not occur every summer, and the pattern was indeed highly irregular (22, 10,11 and 23 years between epidemics, but with cases in-between). The best guess currently is that the ESS outbreaks corresponded to fluctuations in the climate. Random periods of intense rainfall or flooding, or temperature differences which were known to trigger outbreaks over the decades, could account for the seemingly haphazard timing
16. Webbik BE (1842) Luther en Zwingli in 1529, of het Godgeleerd Gesprek te Marburg. G. Portielje, Amsterdam

17. Hardiman J (1820) History of the town and county of the town of Galway. W. Folds and sons, Dublin

18. Anglada C (1869) Etudes sur les maladies éteintes en las maladies nouvelles. Baillière et fils, Paris

19. Banga J (1868) Geschiedenis van de Geneeskunde en Hare Beoefenaren in Nederland. Eeckhoff\&Zoon, Leeuwarden

20. Polwhele R (1806) History of Cornwall. Trewman and son, London

21. Hirsch A (1883) Handbook of Geographical and Historical Pathology 1. The New Sydenham Society.

of the outbreaks. It is however plausible that the population densities of an animal carrier of the causal pathogen could respond to climatic changes, which in turn could explain the pattern. The reported flooding, or long and heavy rainfall preceding the outbreaks could also be responsible for driving the carrier to human habitation for cover and food. Unfortunately, we were not able to find reliable references to numbers of pest species of any kind in the late medieval European literature.

The possibility of another causal agent, besides a hantavirus, cannot be ruled out. Table 2 compares the most common clinical features of the most likely agents of ESS. In our opinion, plague, malaria (the ague, as it was called), influenza and ergotism (most likely the cause of the Dancing Mania) can be ruled out, as those infections were all too well known in those days. Although Yellow Fever, Dengue and Chikungunya could present with similar clinical signs, we fail to see how those pathogens and their vectors would have established themselves for decades in wet, cold England, and only affect the English. From our table, the most likely candidates would be a hantavirus, anthrax and CCHF. CCHF lacks some key signs, and only inhalational or gastrointestinal anthrax infection could give the mortality rates of ESS. There are, however, no contemporary reports of mass animal deaths in those days 
Table 2. Clinical symptoms of the most likely candidates for English sweating sickness

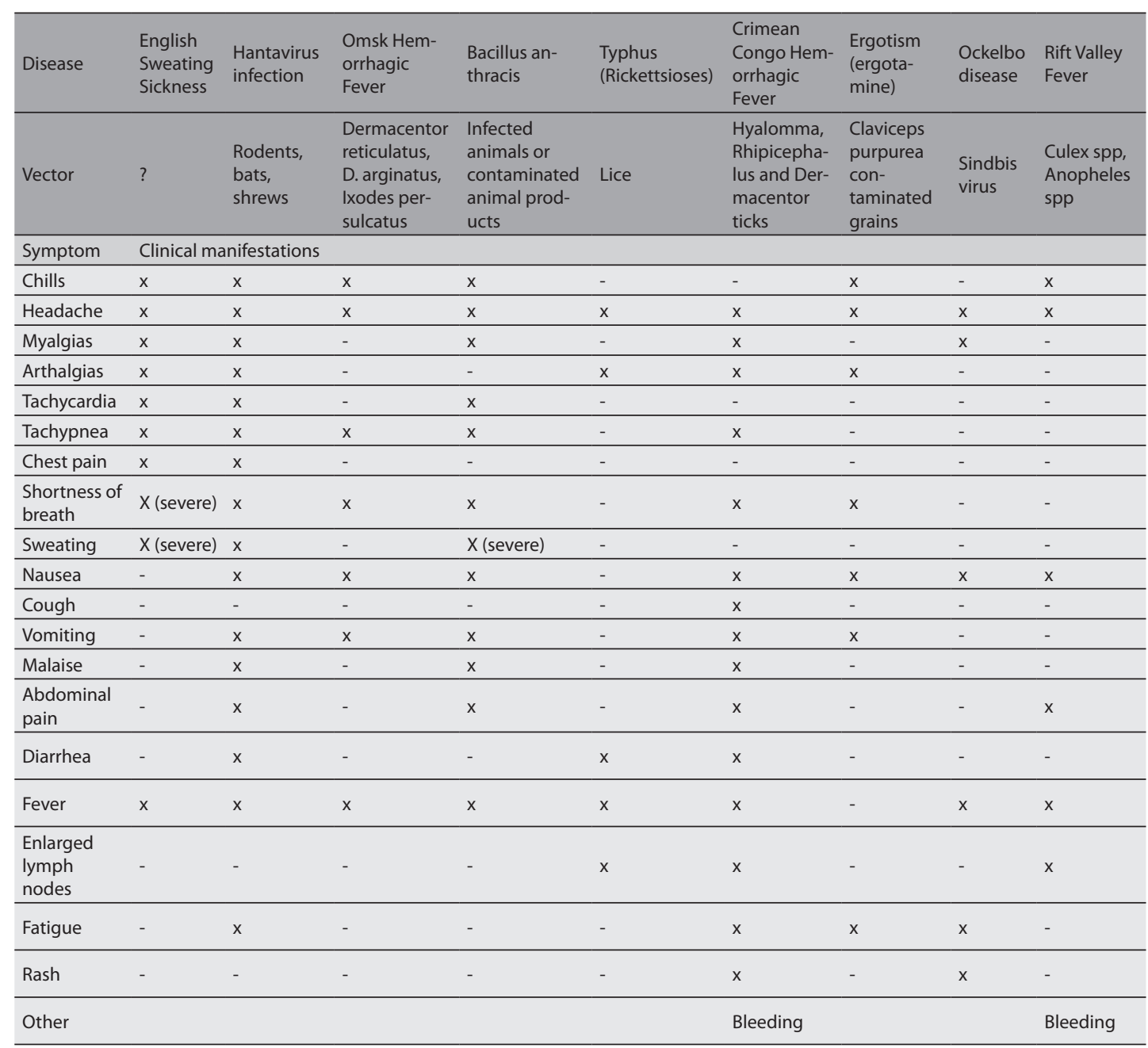

that could explain a nationwide (and in 1529 a continent-wide) epidemic of anthrax disease. Hantaviruses (those that are around today) lack the possible human-to-human transmission, but the ESS bears a fair resemblance to New World hantavirus infections (that are not present as such in Europe today). We hope new techniques or new findings in the contemporary literature will shed light on this subject, but we fear that with the present knowledge of the ESS, we are stuck with the bold Sherlock Holmes' citation: "When you have excluded the impossible, whatever remains, however improbable, must be the truth."
The fact is that the last three decades of the $15^{\text {th }}$ century and first half of the $16^{\text {th }}$ century appear to have been much warmer than the previous 150 years, when the temperature steadily declined after the Medieval Warm Period (1000-1400) (45). It was apparently warm enough to bathe in the Rhine in January in the first half of the $16^{\text {th }}$ century. However, the winter of 1564-65 was the first of many long and bitterly cold seasons (46).

Taking into account that reporting of infectious diseases was not systematic in the $15^{\text {th }}$ and $16^{\text {th }}$ centuries and accounts often appear as a single sentence in a manuscript of several hundreds of pages, it is very pos- 


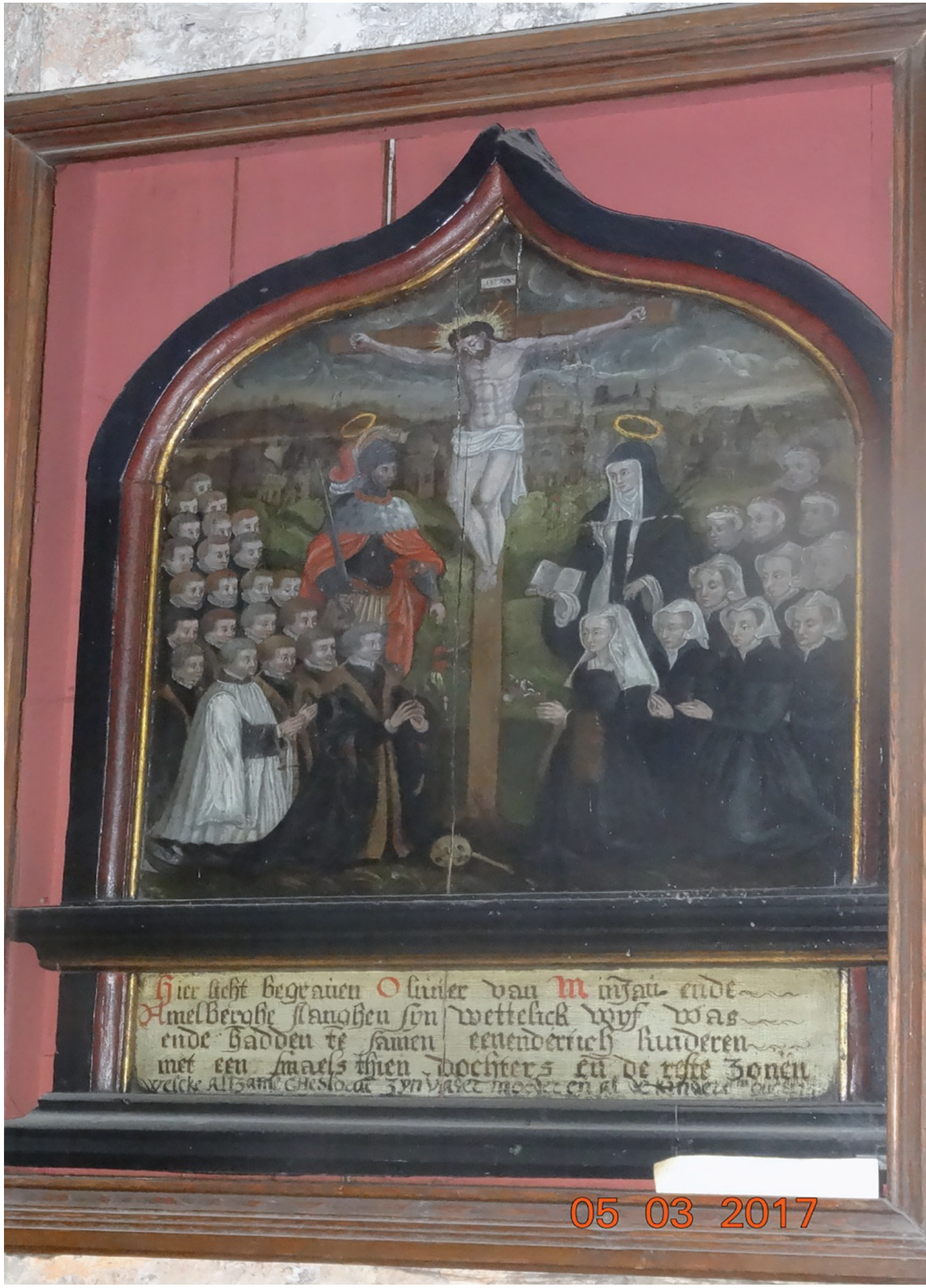

Picture. Epitaph in the Saint Nicolas' Church, Ghent, Belgium with the text: Hier licht begraven Olivier van Minjau ende Amelberghe Slangen syn wettelick wyf was ende hadden te samen eenendertich kinderen met eensmaels thien dochters ende de rest zonen twelck altzamen ghestorven zijn vader moeder ende kinderen in ougsti 1526". (Here lies buried Olivier van Minjau and Amalberghe Slangen, his wife, together with their 31 children, 10 daughters and 21 sons, who all died in August 1526). Source: Paul Heyman 2017. 
sible that more ESS cases occurred than we have traced and that we also missed some manuscripts that could give further information. Some accounts may also have been lost when manuscripts were destroyed. The complete history of the ESS will probably never be written.

However concise, sometimes the information is remarkably detailed and close to home. In Saint Nicolas' Church , Ghent, Belgium, an epitaph is displayed with the text: "Hier licht begraven Olivier van Minjau ende Amelberghe Slangen syn wettelick wyf was ende hadden te samen eenendertich kinderen met eensmaels thien dochters ende de rest zonen twelck altzamen ghestorven zijn vader moeder ende kinderen in ougsti 1526" (Author's translation: Here lies buried Olivier van Minjau and Amalberghe Slangen, his wife, together with their 31 children, ten daughters and 21 sons, who all died in August 1526) (Picture). The cause of death apparently was the ESS, and they all perished within a month of each other, six months after they witnessed the Entry of Emperor Charles V into Ghent on the 24th February 1526 (47-49). This happened therefore three years before the ESS was reported in mainland Europe in 1529, and demonstrates that ESS mortality could be extremely high.

The only disease that resembles the ESS is the Picardy sweat, also called, in French, "la suette des Picards", or "Frieselfieber" in German. It first emerged in the Picardy region (N.W. France), hence its name, in 1718 and caused 196 outbreaks in total between 1718 and 1861, which were mostly localized and often, but not always, more benign than the ESS (50). The Picardy Sweat was mostly confined to France, although not only to the Picardy region, but it was also known in Germany, Belgium, Austria, Switzerland and Italy. Since it emerged some 150 years later than the ESS, much more research has been done into its nature, origin and treatment, and a clear link to rodents was estab- lished (51) but its true nature also remains unknown.

\section{Conclusion}

The English Sweating Sickness, the Picardy Sweat and the Huey Cocoliztl are three in a select group of emerging diseases that have largely escaped medical science. Hantavirus infection remains a possibility, on the basis of the resemblance of the first two to Hantavirus Cardiopulmonary Syndrome or Hemorrhagic Fever with Renal Syndrome, with or without pulmonary involvement.

The contemporary observations that the ESS was clinically different from all "plagues" known at that time, indicates an unknown candidate, possibly viral, and most likely zoonotic. The nature and origin of the English Sweating Sickness, the Picardy Sweat and the Huey Cocoliztl are still medical mysteries and will most probably remain so. We have attempted to demonstrate here that the ESS was more common than generally thought for a long period of time.

As to its origin, ESS was most likely native to England. Neither the assumptions of importation by mercenaries from France not importation from Rhodes seem probable, given the lack of evidence. We investigated the possibility of the transmission of ESS via the Ottoman route, but found nothing to sustain that hypothesis. At the time of the emergence of ESS the Ottomans were reigning in Turkey of course, but they also gradually conquered Eastern Europe (1470 to 1683) up to Vienna. Also in those regions we found no evidence of ESS-like manifestations. The finding was interesting that travel by sea from the Mediterranean Sea Basin to Western Europe in those days was problematic, due to the fact that most major harbors were occupied or besieged by the Ottomans. Therefore, the few Englishmen that fought the Ottomans had to return over land. This took months of travel and again it seems un- 
likely that they could: a) carry the pathogen or vector with them for so long and $b$ ) not start an epidemic along the route.

As many so-called new viruses have emerged or re-emerged in recent decades (HFRS, HCPS, SARS, HIV, MER-coV, Zika, etc.), the English sweating sickness is, however unlikely, still a candidate for re-emergence. What is known on this topic is still too little, as there is no definitive evidence concerning the causal pathogen of ESS. From contemporary writings we can however distill a fairly accurate epidemiological picture. The fact is that ESS had a considerable impact on the European population in the $15^{\text {th }}$ and $16^{\text {th }}$ centuries, as did the Picardy Sweat in the $18^{\text {th }}$ and $19^{\text {th }}$ centuries.

What this study adds to current knowledge is further confirmation of the origin, i.e. the suggestion that it may be a hantavirus, the occurrence of ESS cases in Southern Europe (Spain, Italy), indications that the ESS could have caused casualties well before the generally accepted date of 1485 , further indications that, contrary to the assumed foreign origin of ESS, the disease was indigenous to England, and proof of more cases in between epidemics.

Authors' contributions: Conception and design: $\mathrm{PH}$, $\mathrm{CC}$ and $\mathrm{MH}$; Acquisition, analysis and interpretation of data: $\mathrm{PH}, \mathrm{CC}$ and $\mathrm{MH}$; Drafting the article: $\mathrm{PH}, \mathrm{CC}$ and $\mathrm{MH}$; Revising it critically for important intellectual content: $\mathrm{PH}, \mathrm{CC}$ and $\mathrm{MH}$; Approved final version of the manuscript: $\mathrm{PH}, \mathrm{CC}$ and $\mathrm{MH}$.

Conflict of interest: The authors declare that they have no conflict of interest.

\section{References}

1. Webster N. A brief history of epidemic and pestilential diseases; with the principal phenomena of the physical world, which precede and accompany them, and observations deduced from the facts stated. In two volumes. Hartford, CT: Hudson and Goodwin; 1799.

2. Raine A, editor. York Civic Records, 1485. Volume 1. Leeds: Yorkshire Archaeological Society; 1939.
3. Holinshed R. Henrie The Seuenth. In: Holinshed R. Chronicles of England, Scotland and Ireland: in six volumes. London: J. Johnson, F. C. and J. Rivington; 1808. p. 479-544.

4. Broadberry S, Campbell BMS, van Leeuwen B. English Medieval Population: reconciling time series and cross sectional evidence. Warwick: Leverhulme Trust, Reference Number F/00215AR; 2010. p. 43.

5. Benedictow OJ. The Black Death, 1346-1353: The Complete History. 1st edition. Suffolk: Boydell \& Brewer; 2004.

6. Dean KR. Modeling plague transmission in Medieval European cities [Master of Science Thesis]. Oslo: University of Oslo; 2015.

7. Zinsser H. Rats, lice and history. The biography of a bacillus. London: George Routledge \& Sons; 1935.

8. Creighton, C. The Sweating Sickness, 1485-1551. In: A History of Epidemics in Britain. London: Cambridge University Press; 1891. p. 237-79.

9. Heyman P, Simons L, Cochez C. Were the English sweating sickness and the Picardy sweat caused by hantaviruses? Viruses. 2014;6(1):151-71.

10. Perry RD, Fetherston JD. Yersinia pestis - etiologic agent of plague. Clin Microbiol Rev. 1997;10(1):35-66.

11. Cartwright FF. Disease and History. New York: Thomas Y. Crowell Co.; 1972.

12. Acuna-Soto R, Stahle DW, Cleaveland MK, Terrell MD. Megadrought and Megadeath in 16th Century Mexico. Emerg Infect Dis. 2002;8(4):360-2.

13. Acuna-Soto R, Stahle DW, Therrell MD, Griffin $\mathrm{RD}$, Cleaveland MK. When half of the population died: the epidemic of hemorrhagic fevers of 1576 in Mexico. FEMS Microbiol Lett. 2004;240(1):1-5.

14. Acuna-Soto R, Stahle DW, Therrell MD, Gomez Chavez S, Cleaveland MK. Drought, epidemic disease, and the fall of classic period cultures in $\mathrm{Me}$ soamerica (AD 750-950). Hemorrhagic fevers as a cause of massive population loss. Med Hypotheses. 2005;65(2):405-9.

15. Marr JS, Kiracofe JB. Was the huey cocoliztli a haemorrhagic fever? Med Hist. 2000;44(3):34162.

16. Acuna-Soto R, Romero LC, Maguire JH. Large epidemics of hemorrhagic fevers in Mexico 1545 1815. Am J Trop Med Hyg. 2000;62(6):733-9.

17. Martin PMV, Martin-Granel E. 2,500-year evolution of the term epidemic. Emerg Infect Dis. 2006;12(6):976-80.

18. Beveridge WI. The chronicle of influenza epidemics. Hist Philos Life Sci. 1991;13(2):223-34. 
19. Grob GN. The Deadly Truth: A History of Disease in America. Cambridge, MA: Harvard University Press; 2005.

20. Taubenberger JK, Morens DM. 1918 Influenza: the mother of all pandemics. Emerg Infect Dis. 2006;12(1):15-22.

21. Hippocrates. Hippocrates upon air, water, and situation; upon epidemical diseases; and upon prognosticks, in acute cases especially. To this is added (by way of comparison) Thucydides's account of the plague of Athens The whole translated, methodis'd, and illustrated with useful and explanatory Notes. By Francis Clifton, M.D. Physician to his Royal Highness the Prince of Wales, Fellow of the College of Physicians, and of the Royal Society. London: J. Watts.; 1734.

22. Lowe EJ. Natural Phenomena and Chronology of the Seasons. London: Bell and Daldy; 1870.

23. Lederberg J, Shope RE, Oaks SC Jr., editors. Emerging Infections: Microbial Threats to Health in the United States. Washington, DC: National Academy Press; 1992.

24. Jortin J, Le Clerc J. The Life of Erasmus: from A.D. 1467 to A.D. 1529. Volume 1. London: Richard Taylor \& Co.; 1808.

25. Cantor NF. In the Wake of the Plague: The Black Death and the World it Made. New York: Harper Collins; 2002.

26. Bordier A. On the Special Susceptibility of the Fair-haired Races of Europe for contracting Sweating Sickness. In: Stevenson RK, editor. Reminiscences of a Frequenter to the 1881 Meetings of the Anthropology Society of Paris. London: Stevenson R.K.; 1881. p. 1-6.

27. Webb FC. The Sweating Sickness in England. London: T. Richards; 1857.

28. Southwood Smith T, Ward NB, Arnott N, Toynbee J, Guy WA, Liddle J, et al. First Report of the Commissioners for Inquiring into the State of Lange Towns and Populous Districts. London: William Clowes and Sons for H. M. Stationery Office; 1844.

29. Holinshed R. Holinshed's Chronicles of England, Schotland and Ireland: in six volumes. London: J. Johnson, F. C. and J. Rivington, T. Payne, Wilkie and Robinson, Longman, Hurst, Reese and Orme, Cadell and Davies, and J. Mawman; 1807.

30. Dyer A. The English sweating sickness of 1551: an epidemic anatomized. Med Hist. 1997;41(3):36284.

31. JCOMM Expert Team on Sea Ice. Electronic Chart Systems Ice Objects Catalogue. Version 5.1. [cited 2017 May 1]. Prepared by: Falkingham J, Smolyanitsky V. JCOMM Expert Team on Sea Ice.; 2012. p. 111. Available from: http://globalcryospherewatch.org/reference/other/files/Ice_Objects_Catalogue_V5.1_Draft.pdf.

32. Froude JA. Life and Letters of Erasmus. New York: Charles Scribner's sons; 1894.

33. Hirsch A. Handbook of Geographical and Historical Pathology. Volume 1 - Acute Infective Diseases. London: The New Sydenham Society; 1883.

34. von Marval F. The English sweating sickness with Emphasis on its symptomatology and the Fourth Epidemic of 1529. (Der Englische Schweiss mit berücksichtigung der Symptomatologie und der vierten Epidemie in Jahre 1529) [Doctoral thesis]. Zurich: University of Zurich; 1849.

35. Hecker JFC. The Epidemics of the Middle Ages. London: George Woodfall and Son; 1846.

36. Zeiss H. About the English sweating sickness in Russia: (An epidemiological study on sweating sickness in Eastern Europe. (Uber Englischen Schweiss und Schweissfriesel in Russland: (Eine epidemiographische Vorstudie zur Geschichte der Schweisskrankheiten in Osteuropa). Berlin; G. Reimer. 1921.

37. Hecker JFO. The Epidemics of the Middle Ages. 3rd ed. London, UK: Trübner\&Co, 60, Paternoster Road, London; 1859.

38. Anon. Things that not everybody knows, explained (Dingen die niet iedereen weet, op bevattelijke wijze verklaard). Haarlem: De erven. F. Bohn.; 1863

39. Lebert E. Manual of Practical Medicine. (Manuale di Medicina Practica.) Naples: Presso Nicola Jovene Libraio - Editore; 1874.

40. von Niemeyer F. A text-book of practical medicine, with particular reference to physiology and pathological anatomy. New York: D. Appleton and company; 1874.

41. Heylyn P. Ecclesia Restaurata; or, the History of the Reformation of the Church of England. Cambridge: University Press; 1849.

42. Bryden JL. Epidemic Cholera in the Bengal Presidency. A Report on the Cholera of 1866-1868. Calcutta: Office of the Superintendent of Government Printing; 1869.

43. Murray J. On the Malwah Sweating Sickness. Madras Q Med J. 1840;2:77-98.

44. Orton R. An Essay on the Epidemic Cholera of India. London: Burgess and Hill; 1831.

45. Goosse H, Guiot J, Mann ME, Dubinkina S, Sallaz-Damaz Y. The medieval climate anomaly in Europe: Comparison of the summer and annual mean signals in two reconstructions and in simulations with data assimilation. Glob Planet Change. 2012;84-85:35-47. 
46. Reiter P. From Shakespeare to Defoe: malaria in England in the Little Ice Age. Emerg Infect Dis. 2000;6(1):1-11.

47. Kervyn de Volkaersbeke P. Monuments of Ghent (Monuments de le Ville de Gand). Ghent: La Comission Institué pour leur Conservation; 1852. p. 118.

48. Anon. The Researcher. (De Navorscher). Amsterdam: Ipenbuur \& Van Seldam; 1858.
49. Maes D. Saint Nicolas Church - Wheat Market. (Sint-Niklaaskerk - Korenmarkt). Gendtsche Tydinghen. 1997;1:2-16.

50. Foucart A.The nature and treatment of miliary fever. (De la Suette Miliaire, de sa Nature \& de son Traitement). Labé, Paris: Librairie de la Faculté de Médecine; 1854.

51. Chantemesse MM, Marchoux P, Haury D. Miliary fever and the field vole. (La suette miliaire et le rat des champs). Bull Acad Med. 1906;16:293-302. 